\title{
BACKGROUND INFORMATION FOR THE PAR POND SAFETY AND HEALTH HAZARD ANALYSIS (U)
}

by D. M. Hamby, et al.

Westinghouse Savannah River Company

Savannah River Site

Aiken, South Carolina 29808

WSRC-TR- $-92-303$

DE93 004256

F. W. Whicker

This paper was prepared in connection with work done under Contract No. DE-AC09-89SR18035 with the U.S. Departmant of Energy. By acceptance of this paper, the publisher and/or recipient acknowledges the U.S. Government's right to retain a nonexclusive, royalty-free license in and to any copyright covering this paper, along with the right to reproduce and to authorize others to reproduce all or part of the copyrighted paper.

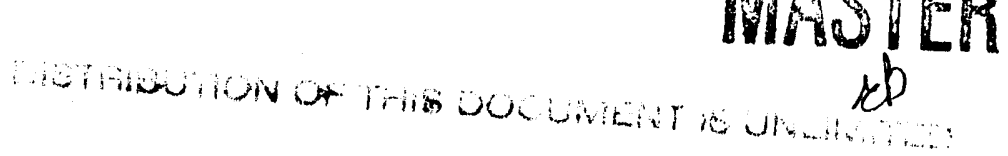




\section{DISCLAIMER}

This report was prepared as an account of work sponsored by an agency of the United States Government. Neither the United States Government nor any agency thereof, nor any of their employees, makes any warranty, express or implied, or assumes any legal liability or responsibility for the accuracy, completeness, or usefulness of any information, apparatus, product, or process disclosed, or represents that its use would not infringe privately owned rights. Reference herein to any specific commercial product, process, or service by trade name, trademark, manufacturer, or otherwise does not necessarily constitute or imply its endorsement, recommendation, or favoring by the United States Government or any agency thereof. The views and opinions of authors expressed herein do not necessarily state or reflect those of the United States Government or any agency thereof.

This report has been reproduced directly from the best available copy.

Available to DOE and DOE contractors from the Office of Scientific and Technical Information, P.O. Box 62, Oak Ridge, TN 37831; prices available from (615) 576-8401, FTS 626-8401.

Available to the public from the National Technical Information Service, U.S. Department of Commerce, 5285 Port Royal Rd, Springfield, VA 22161. 
Background Information for the PAR Pond Safety and Health Hazard Analysis $(U)$

D. M. Hamby (SRTC) and F.W. Whicker (SREL)

The baseline risk assessment [WSRC91] has demonstrated that the hazard at PAR Pond is solely from external exposure to Cs-137, a gamma emitting radionuclide. Between 1954 and 1964, approximately 222 curies of radioactive cesium (Cs-134 and Cs-137) were released to the Lower Three Runs Creek system from $\mathbf{R}$ Reactor [Ma91]. These releases were associated with leaking fuel and target slugs in the reactor disassembly basin. Independent studies show that approximately 45 curies of Cs-137 (half-life of 30 years) still resides in the sediments of PAR Pond [Wh91; Wi91]; Cs-134 has a relatively short half-life ( 2 years) and has decayed to insignificant quantities since it was released.

Existing data were reviewed and evaluated and eventually formed the bases for the CERCLA Baseline Risk Assessment. The data were gathered from several historical documents and annual environmental reports written by WSRC and DOE [WSRC91]. The data from these documents indicated that the maximum measured concentration of Cs-137 in PAR Pond sediments was $122 \mathrm{pCi} / \mathrm{gram}$. For the purpose of being conservative, it was assumed in the risk assessment that this historical "hot-spot" concentration was representative of the entire area of exposed sediments (1300 acres).

Following the PAR Pond drawdown, a number of studies were initiated to characterize the amount of Cs-137 in the pond, the amount of Cs-137 in the exposed sediments, and the hazards associated with radiation exposure at these levels [Ma91; Wh91; Wh92; Wi91; Ha91; WSRC91]. These studies were focused on characterizing the radioactive cesium under current conditions and in much greater detail. 


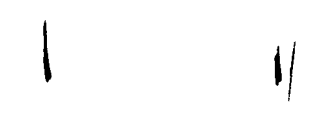

Measurements of the ambient gamma radiation exposure levels were made by SREL researchers using a portable $5 \mathrm{~cm} \times 5 \mathrm{~cm} \mathrm{NaI}$ detector and integral mode scaler [Wh91]. This instrument was calibrated against an NIST-traceable Cs-137 source, as well as a calibrated pressurized ion chamber at 31 different locations. Background radiation (cosmic and terrestrial) was estimated from measurements at 8 locations near PAR Pond but in areas unaffected by the exposed sediments or other sources of contamination. The mean background exposure rate was subtracted from measurements over the exposed sediments to provide estimates of the net increase due to Cs-137 contamination. More than 85 locations in all major areas of the pond were selected for measurements. The net exposure rates generally ranged from 4 to $11 \mu \mathrm{R} / \mathrm{hr}$ with an average of about $8 \mu \mathrm{R} / \mathrm{hr}$ [Wh91].

Researchers in the SRTC have conducted studies to assess the amount of Cs-137 in PAR Pond sediments. An underwater high-purity germanium detector has been used at numerous sites to depths greater than 50 feet. It has been estimated that approximately 42.8 curies of Cs-137 resides in all sediments of PAR Pond with about 9.2 curies being in the sediments exposed (1300 acres) as a result of the current drawdown [Wi91].

Concentrations of Cs-137 in core samples taken by SREL are in very good agreement with SRTC estimates. A number of sediment cores have been collected of both the exposed sediments and the underwater sediments [Wh91]. These cores, ranging in depths from 16 to $38 \mathrm{~cm}$, show that the mean Cs-137 concentration in the upper $10 \mathrm{~cm}$ (where most of the activity resides) is approximately 100 $\mathrm{pCi} / \mathrm{gram}$ dry weight. Total cesium in each core (in $\mathrm{pCi} / \mathrm{cm}^{2}$ ) was estimated by summing the quantities in each depth increment. An overall area-weighted mean, judged to be the most representative for the entire reservoir (above and below water), was $387 \mathrm{pCi} / \mathrm{cm}^{2}$ which equates to a total of about 44 curies over the entire area of the pond [Wh91]. (This estimate of total Cs-137 in PAR Pond sediments agrees very closely with the SRTC estimate.) As for Cs-137 in the 
exposed sediments, the average area concentration in core samples taken above the water level was $226 \mathrm{pCi} / \mathrm{cm}^{2}$.

The radiation exposure limit for workers at the Savannah River Site is currently 3000 mrem per year. Three estimations of the radiation dose received by workers at PAR Pond are shown below. Each estimate is made using independently determined exposure rates or sediment concentrations given above. To be conservative, it is assumed that workers spend 8 hours/day on the exposed sediments for a full work-year (250 days); experience shows, however, that the maximum amount of time spent on the sediments by a PAR Pond worker is about 1.5 hours/day [Ha92].

1.) For the full-time worker ( $8 \mathrm{hrs}$ per day), an average (measured) exposure rate of $8 \mu \mathrm{R} / \mathrm{hr}$ translates to an external dose rate of approximately $16 \mathrm{mrem} / \mathrm{yr}$.

2.) The exposed sediments (1300 acres) contain approximately 9.2 curies of Cs-137. It is, therefore, estimated that the average cesium concentration is $175 \mathrm{pCi} / \mathrm{cm}^{2}$. The external dose rate to an individual standing on the sediments is:

$$
\mathrm{D}=\left(175 \frac{\mathrm{pCi}}{\mathrm{cm}^{2}}\right)\left(6.97 \times 10^{-5} \frac{\mathrm{mrem}-\mathrm{cm}^{2}}{\mathrm{pCi}-\mathrm{hr}}\right)(0.7)\left(2000 \frac{\mathrm{hrs}}{\mathrm{yr}}\right)=17 \mathrm{mrem} / \mathrm{yr}
$$

The factor of 0.7 accounts for ground roughness since the DOE dose factor, $6.97 \times 10^{-5} \mathrm{mrem}-\mathrm{cm}^{2} / \mathrm{pCi}-\mathrm{hr}$, is calculated assuming that ground contamination is in an infinitely thin plane on the surface [DOE88].

3.) SREL estimates an average concentration of $226 \mathrm{pCi} / \mathrm{cm}^{2}$ in the exposed sediments at PAR Pond. The external dose is:

$$
\mathrm{D}=\left(226 \frac{\mathrm{pCi}}{\mathrm{cm}^{2}}\right)\left(6.97 \times 10^{-5} \frac{\mathrm{mrem}-\mathrm{cm}^{2}}{\mathrm{pCi}-\mathrm{hr}}\right)(0.7)\left(2000 \frac{\mathrm{hrs}}{\mathrm{yr}}\right)=22 \mathrm{mrem} / \mathrm{yr}
$$




\begin{abstract}
I II
Radiation dose estimates to PAR Pond workers determined using three different and independent concentration characterization methods are in close agreement. This agreement provides convincing evidence that the dose received by PAR Pond workers exposed to the sediments for an entire work-year is less than $1 \%$ of the DOE radiation limit.
\end{abstract}

\title{
Personnel Protection Requirements
}

The most hazardous chemical or radiological constituent at PAR Pond is Cs-137, a gamma emitting radionuclide. As demonstrated above, the dose received by a hypothetical worker spending 8 hours per day on PAR Pond sediments is less than $1 \%$ of the DOE limit; typically, the maximum exposure time for researchers on the sediments is about 1.5 hours per day [Ha92]. Because of the very low exposures, personnel are not required to wear additional protective items for the purpose of radiation protection. The only feasible way to reduce exposure to employees at PAR Pond is to minimize the amount of time spent on the exposed sediments.

The sediments do not contain sufficient radioactivity to render the material monitorable with portable GM survey meters normally used in health physics practice [Wh92]. However, to provide a record of exposure, it is recommended that the facility owner (Power Engineering) maintain a $\log$ of entrance and exit times for individual employees working at PAR Pond. As an additional precaution, it is recommended that PAR Pond workers wear TLD badges to record external exposure and obtain FASTSCANs on an annual basis to detect any internal contamination. Experience has shown, however, that TLDs, FASTSCANs, and bioassay samples are not likely to yield positive results [Wh92].

\section{Decontamination}

Not only are the doses and health risks from radiation on and around the PAR Pond reservoir well within DOE and SRS guidelines, the 
potential for surface contamination of equipment, tools, clothing, or skin is very slight [Wh92]. The radioactive cesium that entered the Lower Three Runs system is tightly bound to fine sediment particles with transfer coefficients exceeding $10^{4}$. This renders the contamination "non-smearable". Ordinary rinsing removes the particulates and the radioactivity from smooth surfaces; ordinary washing removes the material from fabrics. SREL researchers have smeared and monitored tools used at PAR Pond and have failed to detect any contamination in several dozen trials.

To eliminate the possibility of tracking any contamination from the PAR Pond area, it is recommended that employees rinse sediments from their boots and equipment before leaving. Monitoring prior to exiting the sediment area is not necessary. GM detectors placed directly on the more contaminated portions of the PAR Pond mud flats do not yield readings that are readily distinguishable from background [Wh92].

References

[DOE88] U.S. Department of Energy, "External Dose-Rate Conversion Factors for Calculation of Dose to the Public", DOE/EH-0070, July 1988.

[Ha91] Hamby, D.M., "PAR Pond Soil and Water Concentration Guidelines for Cs-137", SRL-ETS-910533, Westinghouse Savannah River Laboratory, November 1991.

[Ha92] Hamby, D.M., "SRS-Specific Risk Estimates for PAR Pond", SRL-ETS-910603, Rev. 1, Westinghouse Savannah River Laboratory, January 1992.

[Ma91] Marter, W.L. and Boni, A.L., "Summary of Radiological Impacts of PAR Pond Drawdown", SRL-ETS-910579, 
Westinghouse Savannah River Laboratory, December 1991.

[Wh91] Whicker, F.W., "Radioecological Implications of the PAR Pond Drawdown", in 1991 Summary Report of PAR Pond Research, Carol Ercolano (ed), Savannah River Ecology Laboratory, 1991.

[Wh92] Whicker, F.W., "SREL's Evaluation of the Need for OSHA 24 Hour or 40 Hour Training for Performing Work on PAR Pond, Pond C or Pond B", not published, April 1992.

[Wi91] Winn, W.G., "Measurements of Cs-137 in PAR Pond Sediment with Underwater HPGe Detector", SRL-ETS910388, Westinghouse Savannah River Laboratory, November 1991.

[WSRC92] Westinghouse Savannah River Company, "Risk Evaluation of Existing Data for PAR Pond", WSRC-RP-91-1197, Rev. 0, January 1992. 

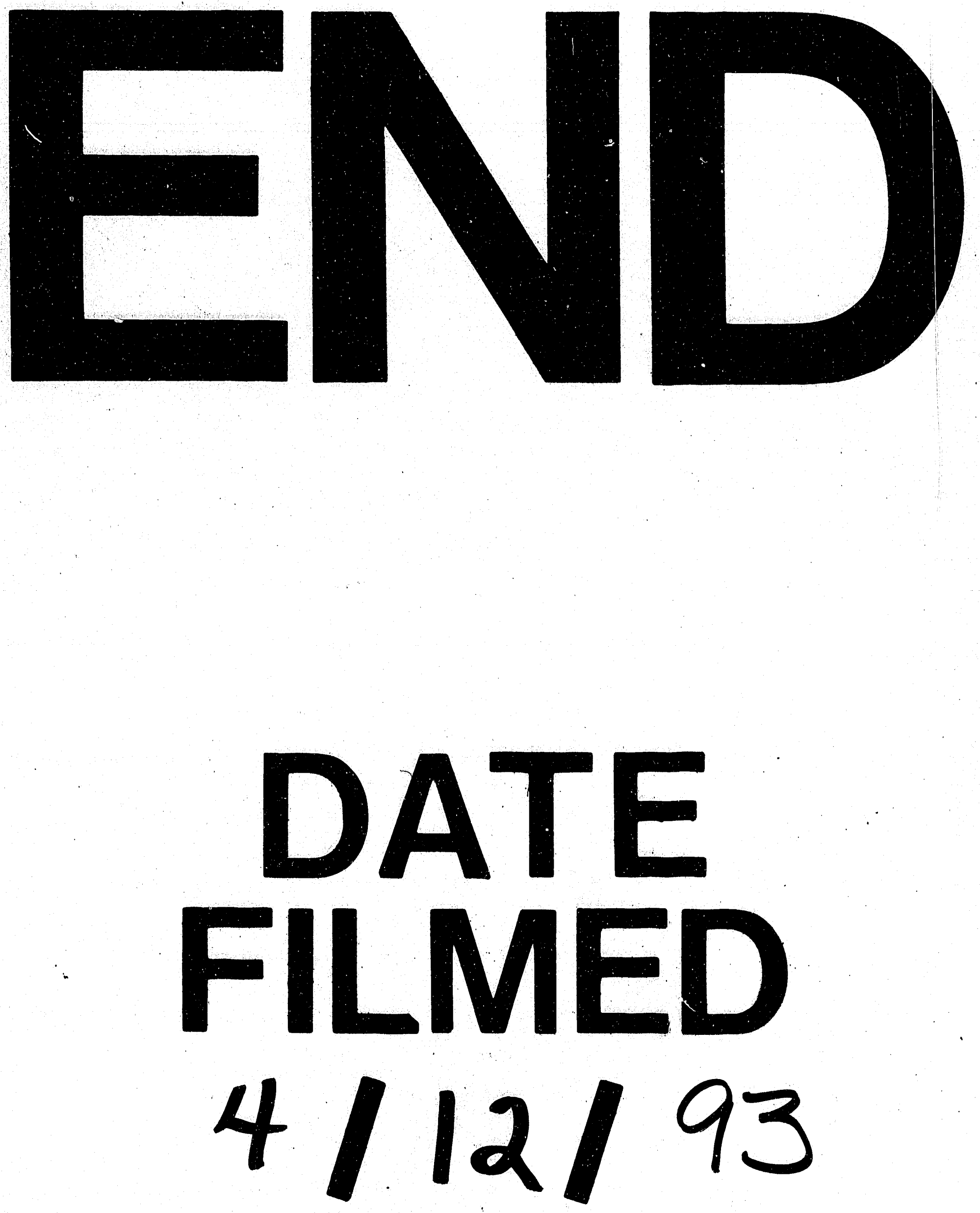
. 